\title{
UNIVERSITY OF CALIFORNIA PRESS PEOPLE'S GUIDES
}

\author{
Los Angeles \\ Greater Boston \\ San Francisco Bay Area \\ Forthcoming \\ New York City \\ Orange County, California \\ Richmond and Central Virginia \\ New Orleans
}

\begin{abstract}
About the Series
Tourism is one of the largest and most profitable industries in the world today, especially for cities. Yet the vast majority of tourist guidebooks focus on the histories and sites associated with a small, elite segment of the population and encourage consumption and spectacle as the primary way to experience a place. These representations do not reflect the reality of life for most urban residentsincluding people of color, the working class and poor, immigrants, indigenous people, and LGBTQ communities - nor are they embedded within a systematic analysis of power, privilege, and exploitation. The People's Guide series was born from the conviction that we need a different kind of guidebook: one that explains power relations in a way everyone can understand, and that shares stories of struggle and resistance to inspire and educate activists, students, and critical thinkers.

Guidebooks in the series uncover the rich and vibrant stories of political struggle, oppression, and resistance in the everyday landscapes of met-

ropolitan regions. They reveal an alternative view of urban life and history by flipping the script of the conventional tourist guidebook. These books not only tell histories from the bottom up, but also show how all landscapes and places are the product of struggle. Each book features a range of sites where the powerful have dominated and exploited other people and resources, as well as places where ordinary people have fought back in order to create a more just world. Each book also includes carefully curated thematic tours through which readers can explore specific urban processes and their relation to metropolitan geographies in greater detail. The photographs model how to read space, place, and landscape critically, while the maps, nearby sites of interest, and additional learning resources create a resource that is highly usable. By mobilizing the conventional format of the tourist guidebook in these strategic ways, books in the series aim to cultivate stronger public understandings of how power operates spatially.
\end{abstract}




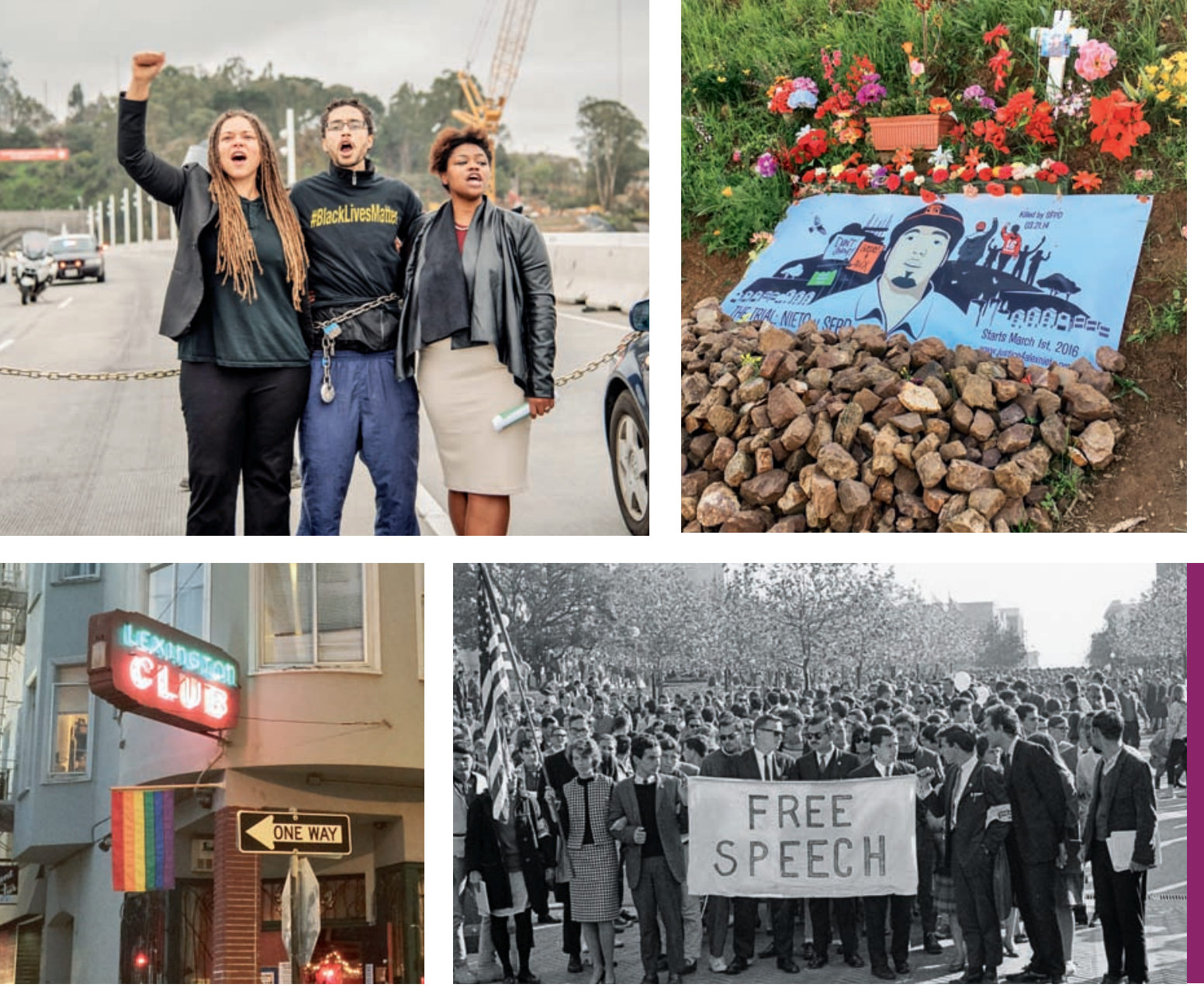

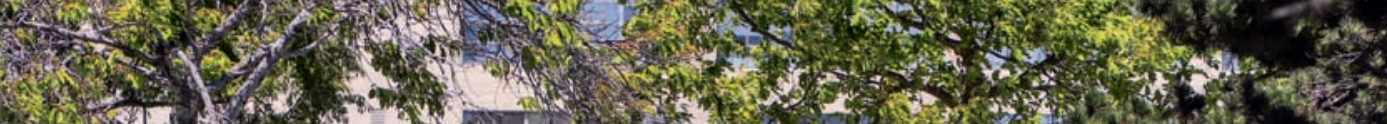

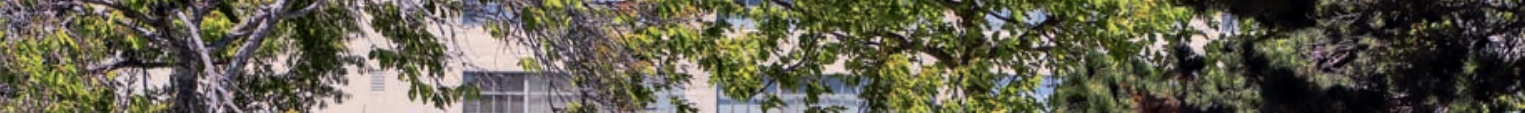

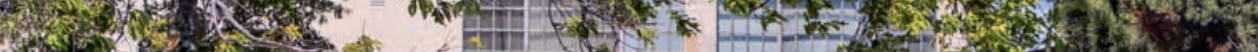

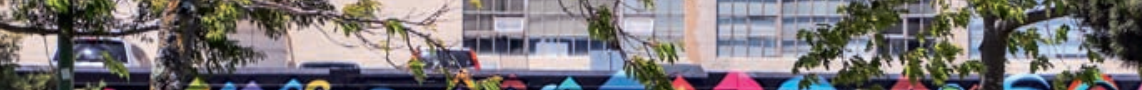

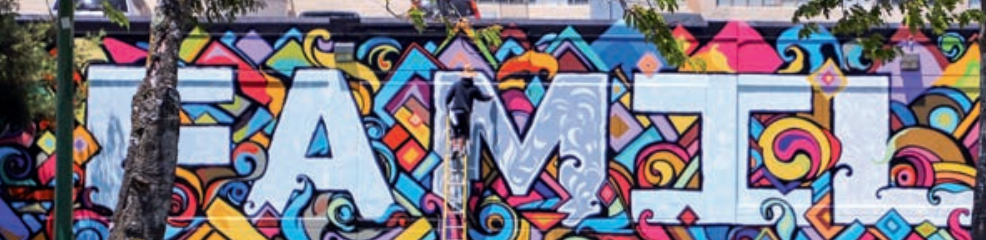

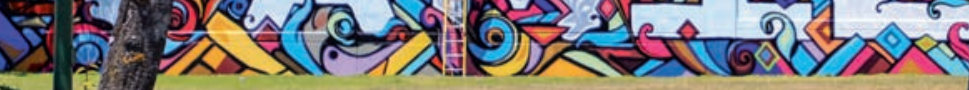
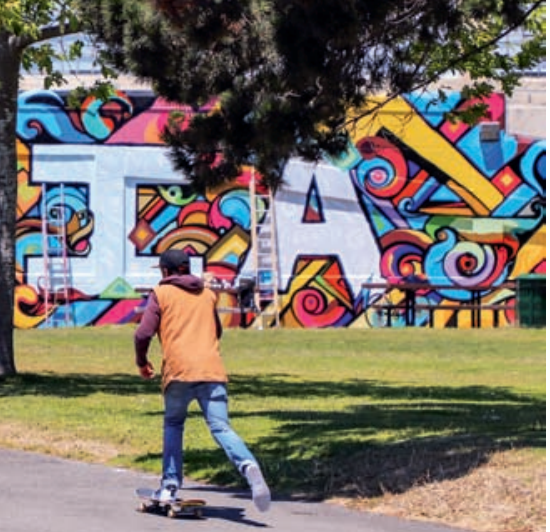


\section{A P E O P I E'S G U I D E TO TH E SAN FRANCISCO BAY AREA}

\section{Rachel Brahinsky and Alexander Tarr}

Photography by Bruce Rinehart

甲

University of California Press 
University of California Press

Oakland, California

(C) 2020 by Rachel Brahinsky and Alexander Tarr

The People's Guides are written in the spirit of discovery and we hope they will take readers to a wider range of places across cities. Readers are cautioned to explore and travel at their own risk and obey all local laws. The author and publisher assume no responsibility or liability with respect to personal injury, property damage, loss of time or money, or other loss or damage allegedly caused directly or indirectly from any information or suggestions contained in this book.

Library of Congress Cataloging-in-Publication Data

Names: Brahinsky, Rachel, I974- author. | Tarr, Alexander, I98I-author. | Rinehart, Bruce, I96I- photographer.

Title: A people's guide to the San Francisco Bay Area / Rachel Brahinsky and Alexander Tarr ; photography by Bruce Rinehart.

Description: Oakland, California : University of California Press, [2020] | Includes bibliographical references and index.

Identifiers: LCCN 2019042832 (print) | LCCN 2019042833 (ebook) | ISBN 9780520288379 (paperback) | ISBN 9780520963320 (ebook)

Subjects: LCSH: San Francisco Bay Area (Calif.)-Description and travel.

Classification: LCC F868.s156 B69 2020 (print) | LCC F868.s156 (ebook) | DDC 917.94/604--dc23

LC record available at https: / / lccn.loc.gov/2019042832

LC ebook record available at https://1ccn.loc.gov/2019042833

Designer and compositor: Nicole Hayward

Text: ro/I4.5 Dante

Display: Museo Sans and Museo Slab

Prepress: Embassy Graphics

Indexer: Susan Storch

Cartographer: Alexander Tarr

Printer and binder: Sheridan Books, Inc.

Printed in the United States of America

$\begin{array}{llllllllll}29 & 28 & 27 & 26 & 25 & 24 & 23 & 22 & 21 & 20\end{array}$

IO $\quad \begin{array}{lllllllll}9 & 8 & 7 & 6 & 5 & 4 & 3 & 2 & \text { I }\end{array}$ 
For our families, given and chosen 
